УДК 811.161.2'373.7

Г. Г. Демиденко

\title{
ВИРАЖЕННЯ ТАНЦЮВАЛЬНОЇ КУЛЬТУРИ УКРАЇНЦІВ ЗАСОБАМИ ФРАЗЕОЛОГІЇ
}

Демиденко Г. Г. Вираження танцювальної культури українців засобами фразеології. У статті з'ясовуються семантичні й етнокультурні особливості українських фразем, які репрезентують специфіку танцювальної культури мовців, описують характер виражальних рухів, надають відомості про невербальний компонент хореографічної практики (пози, жести). Танцювальні здібності українського народу схарактеризовано як унікальне та самобутнє явище, що отримало лінгвальне втілення у сталих зворотах. До аналізу залучено дві групи висловів: 1) фразеологізми із дієслівним компонентом «танцювати»; 2) фразеологізми, внутрішня форма яких засвідчує рухову активність, подібну до танцювальної. Акцентовано, що семантика стійких словосполучень першої групи має метафоричний вияв, стає зрозумілою завдяки культурологічним коментарям, витлумаченню символічного навантаження. Сталі звороти другої групи ілюструють невербальну активність людини, дають оцінку мові тіла, що дає змогу визначити риси характеру українців, ментальні ознаки крізь призму танцювальної культури.

Спостереження за фактичним матеріалом дає підстави зробити висновок, що танець виник у результаті ритуалізації поведінкових стереотипів і сценаріїв. Вони $\epsilon$ виявом загальної потреби до впорядкування танцювальних рухів на біологічній основі як засобів передачі адаптивно цінної когнітивної інформації. Мова танцю зумовлена соціокультурним життям, тому спостереження за тваринним світом, міжособистісне спілкування, міжнаціональні зв'язки, побут, навіть військова справа стали підгрунтям для певних моделей хореографічної культури.

Ключові слова: танець, танцювальна культура, фразеологізм, етнокультура, ментальна модель, ментальний образ, мова тіла, гопак.

Демиденко А. Г. Выражение танцевальной культуры украинцев посредством фразеологии.

В статье определяются семантические и этнокультурные особенности украинских фразем, в которых показана специфика танцевальной культуры носителей языка, которые описывают характер выразительных движений, несут в себе знание про 
невербальный компонент хореографической практики (позы, жесты). Танцевальные способности украинского народа определяются как уникальное и самобытное явление, получившее свое лингвистическое воплощение в устойчивых словосочетаниях. Для анализа взяты две группы выражений: 1) фразеологизмы с компонентом «танцевать»; 2) фразеологизмы, внутренняя форма которых фиксирует двигательную активность, подобную танцевальной. Сделан акцент на тот факт, что семантика фразеологических единиц первой группы имеет метафорическое проявление, становится ясной благодаря культурологическим комментариям, толкованиям символической составляющей. Устойчивые словосочетания второй группы иллюстрируют невербальную активность человека, дают оценку языку тела, что позволяет определить черты характера украинцев, ментальные признаки сквозь призму танцевальной культуры.

Анализ фактического материала дал возможность сделать определенные выводы о том, что танец возник в результате ритуализации поведенческих стереотипов и сценариев. Они являются выражением общей потребности упорядочить танцевальные движения на биологической основе как средства передачи адаптивно ценной когнитивной информации. Язык танца обусловлен социокультурной жизнью, поэтому наблюдения за животным миром, межличностное общение, межнациональные связи, быт и даже военное дело стали базой для определенных моделей хореографической культуры.

Ключевые слова: танец, танцевальная культура, фразеологизм, этнокультура, ментальная модель, ментальный образ, язык тела, гопак.

Demydenko G. G. Ukrainian dance culture expression in phraseology.

This article investigates semantic and ethnic cultural peculiarities of Ukrainian idioms and set expressions, which represent specific dance culture of our nation, describe the nature of expressive movements and provide information about non-verbal components of choreographic practice (posture, gestures etc.). Ukrainians' dance abilities are determined as a unique and original phenomenon, verbally represented in phraseology units. The analysis involves the following groups of set expressions: 1) idioms with verbal "dance" component; 2) idioms with inner component structure which stands for moving activity similar to dance. This paper confirms that the semantics of set expressions in the first group contains metaphorical meaning becoming clear only through additional cultural commentary and symbol interpretation. The idioms of the second group illustrate non-verbal human activity and assess the body language. Their meaning makes it possible to identify Ukrainian mental traits through the prism of dance culture. This research also provides Russian set expressions to emphasize national expressiveness of cultural component in Ukrainian and Belarusian phraseology units, which have the same Eastern Slavic language background.

Factual material observation manifests that the dance originates as a result of behavior and scenario ritualization. Idiomatic units become the way to express general need of regulating person's dance moves on the biological basis as a means of transmitting cognitive adaptively valuable information. Dance language is deeply influenced and caused by social and cultural life. That is why studying of the wildlife, interpersonal communication, international relations, even military affairs contributes to forming certain models of dance culture. Non-linguistic information involved in the research turns to be the source of set expressions in phraseology. This paper illustrates that the set expressions of dance culture contain emotional and evaluative expressiveness and expressive means, 
mostly stylistically reduced, providing a humorous assessment of reality.

Key words: dance, dance culture, idiom, ethnic culture, mental model, mental image, body language, hopak.

Фразеологічний фонд мови нині переживає досить інтенсивний етап вивчення в розвідках, різних за обсягом i спрямуванням. Дослідження усталених висловів, зокрема й 3 позиції національнокультурного маркування, етнологічних рис, ментальних характеристик, постійно привертають увагу лінгвістів (Н. Грозян, М. Жуйкова, Н. Зубець, Т. Князь, О. Левченко, Л. Мельник, О. Ткаченко, В. Ужченко й ін.).

Українська культура багата яскравими народними танцями: гопак, подолянка, козачок тощо. Танець супроводжує молодіжні гуляння (вулицю, вечорниці, весняні й купальські ігрища), а також $є$ обов'язковим елементом весілля [3, с. 590]. У своєму історичному розвиткові український народ створив яскраві та неповторні хореографічні форми, які неодмінно підлягали фразеологізації. Реставрація першоджерел руху дає змогу осягнути i палкий національний темперамент, закорінений у танці, i відображення традицій. Відтак мета нашої статті полягає в тому, аби з'ясувати особливості відтворення у фразеологічному пласті мови танцювальної культури українців. Для реалізації поставленої мети передбачаємо розв'язання таких завдань: 1) виявити в аналізованому матеріалі вислови, які вказують на фізичні рухи, пов'язані з танцем; 2) визначити структурно-семантичні, етнокультурні, стилістичні особливості таких фразем, подекуди зіставляючи лінгвоодиниці з різних мов.

Насамперед відзначимо, що ключовим поняттям дослідження $\epsilon$, передусім, «танець» - полісемантична лексема, що означає, «1) вид мистецтва, у якому художній образ створюється пластичними та ритмічними рухами людського тіла; 2) сукупність пластичних і ритмічних рухів певного темпу й характеру, що їх виконують у такт певній музиці» [1, с. 1430]. Танець, безпосередньо пов'язаний 3 музикою, називається «хореографія». Цей термін походить від грецьких слів «хорео» (танцюю) i «графо» (пишу) і вживається в різних значеннях. У вузькому розумінні - це запис танцювальних рухів за допомогою спеціальної системи знаків, у широкому сенсі - це мистецтво постановки та виконання танців на сцені й танцювальне мистецтво загалом [8, с. 47]. У тлумачному словнику української мови подано таке визначення: хореографія - «мистецтво створення танцю й 
танцювальних вистав» [1, с. 1570].

Як свідчать результати роботи з фразеографічними працями, кількість фразеологічних одиниць (далі - ФО) на позначення танцювальної діяльності українців є досить обмеженою. Особливості реалізації хореографічних умінь у мові дало змогу розглянути фактичний матеріал із двох позицій, а саме: проаналізувати компоненти структури ФО принагідно аналізуючи семантичний обшир, загалом метафоричний і затемнений; і витлумачити внутрішню форму ФО, провівши можливі паралелі між називанням невербального явища із власне тими лінгвоодиницями, які для цього використані.

Українська народна хореографічна культура спричинила появу різних за структурою сталих висловів. Передусім варто звернути увагу на фраземи 3 компонентом «танцювати». Наприклад: танцювати від печі (5, с. 707); танцювати під дудку (5, с. 707); танцювати [аж] штукатурка зі стелі сиплеться (5, с. 780); потанцювати циганської халяндри (5, с. 549); по дорозі кадриль танцювати (5, с. 181).

Як переконує аналіз наведених стійких зворотів, лише ФО танцңювати [аж] штукатурка зі стелі сиплеться має стосунок до танцю як тілесно-фізичної дії, а саме: «(танцювати) важко, 3 шумом» (5, с. 780). Наявність дієслова танщювати у складі інших лінгвоодиниць вказує на джерело виникнення фразем, так чи так пов'язаних 3 руховою діяльністю людини. Стилістично маркований вислів по дорозі кадриль танщңювати використовується в жартівливому контексті, адже називає незграбні, вітіюваті рухи нетверезої людини («іти заточуючись; бути п'яним» (6, с. 181). Цікаво, що така побутова реалія як пияцтво і особливо поведінка особи на підпитку асоціюється 3 побутовим танцем «кадриль». Такі танці беруть свій початок у хороводах і $\epsilon$ основою української народної хореографії. Власне кадриль - це «танець із шести фігур, який виконують пари, що стоять одна проти одної» [1, с. 513]. 3 покликанням на інший народний танець вживається й вираз потанцңювати цицанської халяндри, а саме: «зазнати неприємностей» $(4$, с. 549), де халяндра - «старовинний циганський танець» [1, с. 1555]. У повісті І. Нечуя-Левицького «Старосвітські батюшки та матушки» досить колоритно описано циганську хореографічну культуру: «Музики заграли. Циган повів цчиганок у танець. Циганки почали дикий танець, піднімали руки вгору, крутились на одному місці, тряслись, як в пропасниці, позадиравщи голови вгору. Циган підскакував халяндри ц̆ так немилосердно бив С. Г. Г. Демиденко, 2017. 
себе п'ятами в зад, щуо на йому аж решета стукотіли» [7]. Як зазначає Хв. Вовк, на українських весіллях, зазвичай на перезві, танцювали «журавля - рід кола, болгарського хоро, виконання якого супроводять ріжними еротичними рухами, як, наприклад, хапання один одного за pudenda (статеві органи - Г. Д.). Танцюють також циганську халяндру, що пересякнута так само безсоромним характером» [2, с. 314]. Можемо припустити, що негативна конотація вислову потанцюювати цииганської халяндри зумовлена, не тільки енергійним і подекуди сороміцький характером танцю циган, а здебільшого етнічним ставленням до них особисто. У комунікативному просторі українців ця фразема має й інший варіант - потанц̧ювати і поскакати циганської халяндри (5, с. 549), у якому додатковий дієслівний компонент поскакати підсилює зневажливий тон вислову, створюючи асоціативний зв'язок зі стрибками як елементами циганського танцю.

Мовний аналіз демонструє й утрату прямого зв'язку з руховою діяльністю для ФО танц̧ювати від печі у значенні «бачити в чомунебудь першопричину, початок чогось» $(5$, с. 707). Як нам видається, стрижневе дієслово танц̧ювати імпліцитно вказує на рух думки, іiі плинність у певному ритмі; 3 іншого боку, змістову частину забезпечує іменник піч, адже власне піч виступала символом материнського першопочатку, непорушності родини, неперервності життя, рідної хати, батьківщини [3, с. 456]. Цікаво, що в російській і білоруській мовах вживаються подібні фразеологічні вислови, а саме: рос.: танцевать от печки (8, с. 167), білор.: (запозичення з рос. мови) танцаващь ад печы (ад печкі) (3, с. 354) у значенні «возвращаясь к привычному, простому, повторяя все с самого начала». У коментарях до російського вислову зазначено, що він надає іронічну характеристику позначуваному явищу та має літературне походження. У повісті В. Слєпцова «Хороша людина» йдеться про хлопчика, який вчився танцювати, починаючи свій танець від печі, він збивався з такту, зупинявся і починав усе робити наново, від тої самої печі [9, с. 237]. Очевидно, сталий вислів пов'язаний 3 танцювальною діяльністю. Українська фразема не вказує на «повторення дії, повернення до старту в певних діях», називає інший ментальний образ: «Звичайно, неприємно, щзо в театрі збитки. Але вважати ие головним ми, даруйте, не можемо, і танцювати від цієї печі не слід» (О. Левада) (5, с. 707).

Для успішної реконструкції походження образних виразів на позначення танцювальної культури важливо звертати увагу на «зовнішні 
та функціональні особливості реалій, ті оцінки, які з ними зіставлялися в минулому, специфіку соціальних відносин, поведінкові стереотипи, а також світоглядну базу» [4, с. 30]. Подібні ситуації мали або не мали місце в реальному житті, однак могли бути зафіксовані в літературних творах, здебільшого повчального змісту, регламентувати моральноетичні норми, суспільні ідеали тощо. Творення сталих зворотів на грунті текстів малих жанрів істотно поповнюють фразеологічний фонд. Так, скажімо, вислів танцңювати під дудку означає «беззаперечно виконувати чиї-небудь бажання, підкорюватися комусь у всьому» (5, с. 707). Екстралінгвістичною основою для ФО можна вважати байку Езопа, яку згадує Геродот у першій книзі своєї «Історії», в епізоді 3 біографії перського царя Кіра: «Один флейтист, побачивши риб у морі, став грати на флейті, очікуючи, що вони вийдуть до нього на сушу. Утративши надію, він узяв сітки, закинув їх і витяг безліч риб. Він побачив, як риба б'ється в сітках, і сказав: «Коли я тобі грав, то ти не танцювала. Тепер танцюй, не танцюй - я вже більш не гратиму». Згадується цей вислів й у Біблії. Так, у Свангелії від Матвія й у Свангелії від Луки сказано: «Ми грали вам на сопілці, та ви не танцювали» [10, с. 312-313]. У різних джерелах музичним інструментом є сопілка, дудка, флейта, однак у лексикографічному джерелі фіксуємо ФО танцювати під дудку саме 3 лексемою дудка - «народний духовий музичний інструмент у вигляді порожнистої трубки з отворами» [1, с. 331].

Білоруський лінгвіст І. Лепешев у своїй фразеографічній праці зазначає, що фразема заскакацьь (затанцаваць) пад дудку у значенні «ва ўсім падпарадкоўваючыся каму-н., пачаць выконваць чыю-н. волю» (3, с. 337) є калькою з німецької мови «nach j-s Pfeife tanzen». Білоруська ФО подібна до української за семантикою, однак за структурою має додаткові дієслівні варіанти, належить до функціонально-стильового розряду розмовних фразем (2, с. 57).

У розглянутих вище прикладах сталих зворотів стрижневим компонентом $\epsilon$ дієслово «танцювати», яке безпосередньо впливає на значення вислову, проте трапляються фраземи, що мають це дієслово як лексему-супровідник. У регіональному фразеологічному словнику зафіксовано вислови як цุап на льоду $(6$, с. 517); як ичиганська жила $(6$, c. 204). Обидві мовні одиниці ілюструють особливості виконання танцю, відповідно незграбність, неумілість танцюриста відображено у фраземі як цุan на льоду, де лексема цุan має іронічне смислове навантаження, адже в українській етнокультурі і фольклорі ця тварина С Г. Г. Демиденко, 2017. 
стала об'єктом насмішок, жартівливих характеристик [3, с. 628]. Крім того, у свідомості мовців актуалізується знання про лід, досвід рухової діяльності на слизькій поверхні, тому образ тварини на льоду, особливо в ситуації танцювальної діяльності, корелює з образом невправного, можливо, неповороткого танцюриста.

Інтенсивність хореографії демонструє вираз як циганська жила - «дуже сильно, жваво» (6, с. 204), у якому динамічний образ спритного, в'юнкого цигана постає основою для утворення фразеологічного значення. Відповідно соматичний іменник жила «судина, по якій тече кров у тілі людини чи тварини» [1, с. 367] посилює експресію фразеологізму. Як відомо, великі судини людського організму мають здатність пульсувати та напружуватися від приливу крові, тому, очевидно, спостереження за основними артеріями під час фізичних навантажень, зокрема танців, $\epsilon$ пропотиповою ситуацією для ФО.

У фразеологічному фонді мови фіксуємо й такі лінгвоодиниці, що демонструють хореографічну майстерність завдяки наявності в їх складі компонентів-назв частин тіла, які беруть участь у танці: плести (писати, виписувати) кренделі ногами (5, с. 518); дати волю ногам (5, с. 177); викидати колінця (5, с. 72) та ін.

Образність фразеологізму дати волю ногам у другому значенні «завзято, запально танцювати» $(5$, с. 177$)$ пов'язана 3 семантичним спектром лексеми воля - «відсутність обмежень; привілля» [1, с. 202], (пор.: давати волю ногам $\leftarrow$ давати (дати) волю кому, чому - «не обмежувати когось у діях, у виявленні почуттів, не стримувати своїх почуттів» [1, с. 202]). Іншими словами давати волю ногам сприймається мовцем як «не обмежувати рухи ногами, зокрема й у танці».

Жартівливу оцінку танцювальній діяльності надає вислів плести (писати, виписувати) кренделі ногами, який у першому значенні називає ходу п'яної людини. Інше витлумачення («танцюючи, робити незвичні па» (5, с. 518) має специфічну сему «незвичний», що, на нашу думку, вказує на небуденність рухів, певну ексцентричність у танці. Образ нетверезої людини, яка рухається криво, і нетипового виконання танців підсилює лексема крендель - «виріб із тіста (звичайно здобного), формою схожий на вісімку» [1, с. 585]. Саме геометрична форма кренделя, вочевидь, стає підгрунтям для «прототипової ментальної моделі» (за термінологією М. Жуйкової) у процесі встановлення внутрішньої форми стійкого звороту. Подібні 
процес фраземотворення вбачаємо й у вислові 3 матеріально не вираженим соматичним компонентом, а саме: виписувати калачі («витанцьовувати» (6, с. 323), де калач - «білий хліб особливої форми, випечений із крученого й переплетеного тіста» [1, с. 515].

3-поміж аналізованого матеріалу варто прокоментувати міжмовні відмінності в номінації знаків танцювальної діяльності, а саме: рос. выкидывать кренделя - «лихо, замысловато отплясывать» (7, с. 94) та полісемантичні укр. викидати колінця (5, с. 72), викидати кренделі (5, с. 72) - «1) робити вигадливі рухи, фігури в танці; витіювато танцювати; танцювати до одуру; 2) здійснювати, робити якийсь несподіваний, нерозумний або легковажний вчинок; 3) співати, роблячи несподівані переходи в тональності, силі і висоті звуків». 3 соматизмом колінще пов'язаний російський вислів откальввать коленце - «совершать, делать что-либо несуразное, необычное» (7, с. 302), що, однак, не фіксує специфіки руху й відповідає українській одиниці лише в їі другому значенні.

Фразеографічною практикою зафіксовані й інші «танцювальні» фразеологізми, позбавлені соматичного компонента. Проте вони мають у структурі лексеми, що називають частину взуття, яка бере на себе найбільше навантаження в танці - закаблук («задня частина взуття, що охоплює п’яту» [1, с. 393]). Наприклад: ударити в закаблуки (5, с. 733); дати лиха закаблукам (закаблам) (4, с. 179); садити закаблуками $(5$, с. 628$)$ та ін. Названі вислови мають яскраве емоційне тло, адже надають безпосередню характеристику танцю, сповненого емоцій і переживань, як-от: завзято танцювати, із запалом, темпераментно. Подібний до названих виразів й зафіксований словниками фразеологізм зі стилістично зниженим жартівливим забарвленням оббивати каблуки, що означає «енергійно, темпераментно, багато танцювати» $(5$, с. 444$)$.

Енергійність виконання танцю, у творчому піднесенні, 3 припливом душевних сил ілюструє вислів кресати підковами (підківками, чобітьми) (5, с. 312), де кресати - 1) добувати іскри, вогонь кресалом // ударяючись або вдаряючи чимось об сталь, камінь, утворювати іскру; 2) сильно вдаряти, сікти; 3) пристрасно, 3 запалом робити, виконувати що-небудь [1, с. 585]. Можемо припустити, що ФО пов'язана саме 3 третім значенням дієслова, зважаючи на його метафоричність. Варто зауважити, варіювання слів-компонентів (nідкова, чобіm) не змінюють образ, що ліг в основу денотативного значення, адже ці варіанти постають унаслідок метонімічних С Г. Г. Демиденко, 2017. 
взаємозамін, де підкова - «металева пластинка, що набивається на спід взуття; також каблук на жіночому взутті» [3, с. 454].

Протягом багатовікової історії народу українські танці збагачувалися та видозмінювалися. I до таких танців належить гопак, у якому знаходить своє відображення героїзм боротьби, національні традиції, культурні та мистецькі цінності українського народу. У традиційних рухах емоційного гопака збереглися не тільки духовність і містика глибини тисячоліть, але і гармонійна система стародавнього військового мистецтва наших предків. Завдяки цьому гопак знайшов своє втілення у двох формах: як танець і як бойове мистецтво [5]. Історію виникнення гопака пов'язують 3 бойовими тренуваннями козаків Запорозької Січі у XVI-XVIII ст. [6].

У мовній практиці побутують вислови, пов'язані з козацьким танцем. Наприклад: гопака оддирати (садити) - «танцювати гопака із запалом» (4, с. 124) і подібні ударити (утнути) тропака [1, с. 1480]; вибивати (бити, садити, утинати) тропака (4, с. 283), що означають «танцювати тропака завзято, із запалом», де тропак - «український народний танець, за характером виконання близький до гопака $[1$, c. 1480]. Власне іменник гопак і відповідно ФО спродуковані на основі значення вигуку гоn - «звуконаслідування, яким супроводжується стрибок, притупування в танці» [1, с. 253]. В етимологічному словнику української мови зазначено: «Гоп (вигук), гопа, гопашеньки, гопати, гопкати, гопцювати, гопак (танець), гопи і гопки «стрибки в танці» (вдарити в гопи «танцювати»)» (1, с. 561). За таких умов культурно-національної конотації набувають сталі звороти гопки йти («танцювати» (5, с. 284), гопки витинати («танцювати, підстрибуючи, притупуючи» (4, с. 124) завдяки лексемі гопки, що «виражає спонукання до скакання, стрибання, тупотіння» [1, с. 253] (пор.: вибрикувати гопки - «дуже радіти» $(5$, с. 63).

Отже, проаналізовані фразеологізми демонструють яскраві зразки танцювальної культури українців, що завдяки особливостям номінації чи семантичним модифікаціям набувають етнокультурного змісту. Більшість із них пов'язана 3 емоційними переживаннями мовців, міжнаціональними зв'язками. Через невербальні елементи у структурі висловів простежуємо й риси національного характеру, специфіку соціальних взаємин. Перспектива подальших досліджень полягає у вивченні лексичних номінацій танцювальної діяльності українців, зокрема назви танців. 


\section{Література}

1. Великий тлумачний словник сучасної української мови / [уклад. і голов. ред. В. Т. Бусел]. - К.-Ірпінь : ВТФ Перун, 2009. - 1736 с.

2. Вовк Хв. Студії з української етнографії та антропології / Хв. Вовк. - Прага : Український громадський видавничий фонд, 1928. - 354 с.

3. Жайворонок В. Знаки української етнокультури : [словник-довідник] В. Жайворонок. - К. : Довіра, 2006. - 703 с.

4. Жуйкова М. В. Динамічні процеси у фразеологічній системі східнослов'янських мов : [монографія] / М. В. Жуйкова. - Луцьк : РРВ «Вежа», 2007. - 416 с.

5. Кіптілова Н. Гопак як один 3 феноменів українського танцю / Н. Кіптілова // Вісник Львівського ун-ту. Серія мистецтво. - Львів, 2014. - Вип. 14. - С. 75-80.

6. Купленик В. Козацький танець. Нариси з історії українського народного танцю [Електронний ресурс] / В. Купленик. - К., 1999. - Режим доступу : http://www.redkyb.ru/boh/dans/bookstan/doslid2-5.html

7. Нечуй-Левицький I. С. Старосвітські батюшки і матушки [Електронний ресурс] / I. С. Нечуй-Левицький. - Режим доступу : http://ukrlit.org

8. Фриз П. Хореографічна культура в контексті теорії і практики сучасного суспільства / П. Фриз // Молодь і ринок. - 2012. - № 8. - С. 46-50. - Режим доступу : http://nbuv.gov.ua

9. Шанский Н. М. Школьный фразеологический словарь русского языка : значение и происхождение словосочетаний / Н. М. Шанский, В. И. Зимин, А. В. Филлипов. [4-е изд., стереотип.]. - М. : Дрофа, 2001. - 368 с.

10. Шестеркина Н. Коды культуры лексем Tanz («танец») и tanzen («танцевать») в составе немецких фразеологизмов / Н. Шестеркина // Музыкальные мотивы во фразеологии : сб. научн. ст. - Братислава, 2014. - 373 с.

\section{Список використаних джерел}

1. Етимологічний словник української мови : у 7-и томах. - Т. 1 : $A-\Gamma$. - К. : Наук. думка, 1982. $-632 \mathrm{c}$.

2. Лепешаў І. Я. У фразеалагічную скарбонку : [даведнік] / І. Я. Лепешаў. - Гродна : ГрДУ, 2004. - 149 c.

3. Лепешаў І. Я. Этымалагічны слоўнік фразеалагізмаў / І. Я. Лепешаў. - Мінськ : БелЭн, 2004. - 448 с.

4. Словник української мови : в 11 т. / [за ред. І. К. Білодіда]. - К. : Наук. думка, 1970. - T. 2. -552 c.; T. $10 .-660$ c.

5. Словник фразеологізмів української мови / [уклад. В. М. Білоноженко та ін.]. К. : Наук. думка, 2003. -1104 с.

6. Ужченко В. Д. Фразеологічний словник східнослобожанських і степових говірок Донбасу / В. Д. Ужченко, Д. В. Ужченко. - [6-е вид., перероб. й доп.]. Луганськ : Вид-во ДЗ «ЛНУ ім. Тараса Шевченка», 2013. - 552 с.

7. Фразеологический словарь русского языка [свыше 4000 слов. статей] / [под. ред. А. И. Молоткова]. - [2-е изд., стереот.]. - М. : Советская энциклопедия, 1968. - 543 с.

8. Яранцев Р. И. Словарь-справочник по русской фразеологии : (ок. 800 фразеологизмов) / Р. И. Яранцев. - [2-е изд., стереотип.]. - М. : Русский язык, 1985. - $304 \mathrm{c}$.

Стаття надійшла до редакиії 26.05.2017 p. 